\title{
Small Business And Entrepreneurship Financing System In Uzbekistan: Historical Analysis And Approaches
}

\author{
Fayzulla Tolipov \\ Associate Professor, Candidate Of Historical Sciences, Independent Researcher, National \\ University Of Uzbekistan
}

Journal Website:

http://usajournalshub.c om/index,php/tajssei

Copyright: Original content from this work may be used under the terms of the creative commons attributes 4.0 licence.

\section{ABSTRACT}

The article describes the specifics of the system of financing of small business and entrepreneurship in the recent history of Uzbekistan, the funds allocated for small business and entrepreneurship, the activities of commercial banks and the financial and banking system, some problems in the field. It also noted that since the early days of independence, a unique business environment has been created in the country to support the interests of entrepreneurs in the framework of development programs in this area, data on the role of financial mechanisms in the further development of small business and entrepreneurship in the country have been studied from a historical point of view. The article highlights the positive situation in the country's macro and microeconomic indicators, ie the active participation of banks in attracting local entrepreneurs and foreign investment, the existing problems in this area and the measures taken to address them. It analyzes the important factors and strategies of banks' participation in the development of business and entrepreneurship.

\section{KEYWORDS}

Small business, entrepreneurship, banking and financial system, commercial bank, capital, microcredit, historical analysis, reform, investment, enterprise, owner, sector, program, commodity, export, savings, trade, payment, subject. 
There is no doubt that the proper conduct of banking in any country, the formation of a healthy competitive environment in the banking system and the creation of its legal activities will create a favorable business environment for entrepreneurship and private business in this country. Uzbekistan, as in the developed countries of the world, has accumulated a unique historical experience in the effective use of banking in the development of entrepreneurship. If we pay attention to the historical experience of the developed countries of the world, the financing of small business and entrepreneurship is the most important direction of state economic policy. During the years of independence, the scale of financial allocation by banks on the basis of the principle of "Bank-entrepreneur”, "Entrepreneur-bank" began to expand. In this regard, in order to provide financial assistance to businesses, measures have been taken to ensure that commercial banks become a unique business partner.

At the same time, there are still bureaucratic hurdles and obstacles in the regions and districts of the country due to the inability of entrepreneurs to receive sufficient funds from banks in a timely manner or support, and the lack of clear coordination of relevant ministries and agencies.

\section{THE MAIN FINDINGS AND RESULTS}

In recent years, in the history of Uzbekistan, important steps have been taken to ensure the development of small business and entrepreneurship, to bring their activities to a new level. In this regard, loans provided by banks are an important step in financing entrepreneurship and small business. In 1991, the Law of the Republic of Uzbekistan "On Banks and Banking Activities" was adopted, the use of loans to individuals and legal entities, the right to sell credit resources through auctions in the interbank money market was an important event. "The Savings Bank of Uzbekistan has opened branches in 187 districts and cities of the country. If we look at the historical figures, in 1994 and the first six months of 1995 alone, loans totaling 1,223.3 million soums were issued to small and rental enterprises, as well as companies and entrepreneurs [1.581].

Specialized joint-stock commercial banks Agrobank, Gallabank, Mevasabzavotbank, Tadbirkorbank, Savdogar and others - have been established in the country. These banks have been providing investment funds in the interests of entrepreneurship, the development of small and medium-sized businesses, the enrichment of the consumer market with the necessary goods [2.581].

According to historical analysis, as the volume of loans issued by banks to small businesses and entrepreneurs has increased, trade relations of Uzbekistan with neighboring countries, especially the CIS, have begun to expand. In this regard, A. According to Akimov, the interaction of these countries with each other, economic relations with the CIS and nonCIS countries, the existence of an open market is the first step towards entering the modern world economy. Because any economic reforms in the Central Asian Republics determined their participation in international economic relations [3. 275-293]. This process is 
also evident in the microcredit system of banks in the region [4.130-140].

Credit resources of foreign investors and the world's leading banks, including the European Bank for Reconstruction and Development, the German Bank for Reconstruction and Development, the Asian Development Bank, the International Finance Corporation and other international financial institutions were used to develop small business. In 1999 alone, small businesses received more than $\$ 200$ million in loans from the European Bank for Reconstruction and Development, the German Bank for Reconstruction and Development, and the Asian Development Bank [5 388].

In order to provide advice to entrepreneurs and businessmen, the German Society for Technical Assistance has opened a small business support center in Uzbekistan, and the European Commission has opened a Center for Practical Relations. The American Entrepreneurship Fund in Central Asia and the British Investment Fund in Central Asia provided necessary assistance to Uzbek entrepreneurs [6. 286-287]. In 2001, in accordance with the agreement between the Privatization Bank of Uzbekistan and the German KFB Bank, 3.7 million marks were allocated and 6 projects were financed [7.279].

In general, as of January 1, 2002, the National Bank for Foreign Economic Activity provided loans in the amount of $\mathbf{2 1 3 . 6}$ million US dollars, Asaka Bank in the amount of 52.0 million US dollars, and other banks in the amount of 34 million US dollars [8.3].

Undoubtedly, this meant further accelerating the implementation of reforms in the field of small business financing. In this regard, a number of achievements have been made in the history of our country. In particular, the volume of lending to small business and private entrepreneurship by Microcreditbank, established in 2006, has increased fourfold and more than 150 billion soums have been allocated for these purposes. On the basis of the presidential decree, it was decided to increase the authorized capital of "Microcreditbank" by 72 billion soums and increase its volume to 150 billion soums [9.6364].

According to historical research, the country's economy has a large lending potential, the main share of which falls on small businesses. Banks have relied on the principles of fast, simple, convenient and modern service in nontraditional lending to small businesses. In 2008 alone, $68.2 \%$ more than in the previous year, or about 1,250 billion soums were allocated to finance business organization and development projects, which means that the volume of loans for these purposes has increased [10.589].

In order to facilitate the establishment of small businesses, in the first 9 months of 2012, 55 state-owned assets worth 19.4 billion soums were sold to small businesses and private entrepreneurs, and about 17.6 thousand unused state-owned facilities were leased. Commercial banks issued loans worth 4.2 trillion soums (an increase of 1.3 times compared to the same period in 2011) to small businesses and private entrepreneurship, including microloans worth 857.2 billion soums (an increase of 1.4 times). The volume of public procurement from small businesses amounted to 229.1 billion soums (92.9\% of the total volume of public procurement through etenders), more than 7,000 small businesses participated in the public procurement system with their goods and services [11.8.12. 2012]. 
As a result of the implementation of regional employment programs in the country, support and development of family business, in 20052011 alone, 3.8 million new jobs were created in all sectors of the economy. More than $74 \%$ of them are in the field of small business and private entrepreneurship. It should be noted that in order to create new jobs and increase employment, commercial banks provide more than 1 trillion soums of loans annually for small business and private entrepreneurship [12.151].

If we look at the historical figures, the amount of microcredits provided by JSCB "Agrobank" and OJSCB "Microcreditbank" on the basis of "Bank-entrepreneur", "Entrepreneur-bank" to micro-firms, family businesses, farmers and farms has grown from year to year. For example, the amount of microcredits allocated in 2009 amounted to 90.8 billion soums, which is 120 billion soums more than in 2008. In addition, real incomes increased by $26.5 \%$ [ 13 . 344]. In 2013, this figure increased from 90.8 billion soums in 2009 to 245.8 billion soums [ 14 . 92]. The volume of microcredits allocated by Microcreditbank to support women's entrepreneurship in 2009 amounted to 18.4 billion soums, in 2013 this figure amounted to 56.8 billion soums, an increase of 2.2 times [ 15 . 93].

But there are also some problems in this regard, which are as follows:

- Problems related to cases of illegal interference of state and various regulatory authorities in the activities of small business and private entrepreneurship in this historical period;

- In the non-governmental sector of the economy there are monopolistic associations, enterprises, which have established their dominance in the markets of domestic consumer and means of production, artificially raising prices;

- Improper interference of state trustees in the activities of joint-stock companies in the business sector due to the large share of the state in the charter capital and shares;

- The tight control of the banking and credit system and the foreign exchange market by the state has reduced the free access of enterprises and entrepreneurs to foreign markets, etc.

Also, due to the underdevelopment of production infrastructure, entrepreneurs had difficulty obtaining material and technical resources, financial resources, loans. These unfortunate circumstances necessitated the further liberalization of economic life, the expansion of freedoms of entrepreneurship and economic activity, and the further elevation of the status of private owners. As a result of urgent measures taken by banks in the country entered a new stage of business development.

In 2011-2012, the Central Bank of Uzbekistan will gradually introduce new recommendations of the Basel Committee on Banking Supervision, as well as measures to improve control over the activities of non-bank credit institutions. In addition, a new system has been developed to assess the performance of commercial banks and the entire financial and banking system, based on the criteria and standards used by leading international rating agencies to evaluate and analyze the activities of financial institutions [16.125].

For example, the role of the Export Promotion Fund for Small Business and Private Entrepreneurship, established under the National Bank for Foreign Economic Activity, is 
growing. The Fund provides legal, financial and organizational services to businesses to promote their goods and services in foreign markets. In 2015, more than \$ 840 million worth of goods were exported under bilateral agreements. In 2016, with the support of the Fund, export contracts worth \$ 1 billion 250 million were concluded by business entities [17.52]. In order to implement the requirements of this agreement, comprehensive measures were taken in the country.

According to it, in order to create new jobs and increase employment in 2016, more than 1 trillion soums of loans were issued annually by commercial banks for small business and private entrepreneurship [18. 38]. In order to provide financial support to small business and private entrepreneurship, banks issued 12.1 trillion soums in 2016. UZS, which is 1.3 times more than in 2015, and 2.5 trillion soums of microcredits, this figure also is 1.3 times higher than in 2015 [19.8].

In the renewed Uzbekistan, a new stage has been entered in the provision of entrepreneurs with bank loans, liberalization of the banking sector. In particular, in 2017, the total capital of commercial banks increased 2.3 times and reached 20.7 trillion soums. The capital adequacy ratio increased by $18.8 \%$, which is 1.8 times higher than international norms. The total volume of attracted deposits of commercial banks increased by 1.6 times and amounted to 58.7 trillion soums. The total assets of banks doubled and as of January 1, 2018 amounted to 166.6 trillion soums [20.8]. As a result, at a new stage of development, Uzbekistan has risen from 154th to 42nd place in the world in the last 3 years on the indicator called "Lending to small businesses" and last year improved its ranking by 63 positions [ 21 . 41].

In 2018, as a result of the banks' continued active credit policy, the total volume of loans to the real sector of the economy increased 2.1 times and amounted to 110.6 trillion soums. In particular, 16.1 trillion soums were allocated by commercial banks to finance investment projects, which is 1.3 times more than in 2016 [22. №26]. The total volume of loans to the real sector of the economy increased by $27.3 \%$ compared to 2015 and as of January 1, 2016 amounted to 42.7 trillion soums [23.9].

Until May 2020, more than 500,000 businesses and more than 8 million citizens have been provided with benefits and preferences worth about 30 trillion soums. According to the Decree "On the next measures to support the population and businesses during the coronavirus pandemic" adopted on May 18, 2020 , it is planned to provide additional 1.7 trillion soums to about 100,000 people in the future [24.104]. In this regard, in order to provide financial assistance to businesses, a new concept has been introduced to ensure that commercial banks become a unique business partner. As a result of such systematic practical measures, 70,000 new business entities were created in the past 8 months of 2019. This is 2 times more than in the same period of 2018 [25. №189].

However, research has shown that in our country there are some problems in creating ample opportunities for entrepreneurs and raising the international rating of the industry. For example, in the World Bank's Doing Business ranking, Uzbekistan ranks 134th in construction. There are also 17 construction permits in Uzbekistan, which take an average of 246 days to obtain [26. 20]. Of course, the 
current state of opportunities and conditions created for entrepreneurs in our country today is not enough to compare with foreign countries.

Therefore, over the past 4 years, the work in this area is being critically reviewed and the necessary measures are being taken to eliminate these problems. In particular, in 2018, the President of the Republic adopted a resolution "On measures to further improve the rating of the Republic of Uzbekistan in the annual report" Doing Business "World Bank and International Finance Corporation" [27. 2018].

It was noted that the existing conditions for doing business in Uzbekistan still do not meet the requirements of international norms and standards, and some government agencies do not adequately ensure the implementation of reforms to develop entrepreneurship. In particular, the President instructed the Cabinet of Ministers to consider the necessary measures to improve the norms and regulations in this area [28.20], not in vain.

In order to create a favorable investment climate, especially for attracting foreign direct investment to the country, liberalize the economy, reform public administration, limit interference in the activities of business entities, licensing and in order to reduce and simplify the permitting procedures, on August 1, 2018, the Presidential Decree "On measures to radically improve the investment climate in the Republic of Uzbekistan" was issued. The decree emphasizes the need to further improve the investment climate, encourage the attraction of direct investment, strengthen investment confidence in the consistency of public policy in this area.
It also highlights current issues in the field over a number of years, which are reflected in the following:

- Investors may not be able to get enough funds from banks in a timely manner or are not supported;

- There are still bureaucratic hurdles and obstacles related to the lack of clear coordination of the activities of relevant ministries and agencies in this regard;

- Reducing the tax burden and problems in the taxation system for investors and their elimination [29.2018].

The decree stipulates strict control over the financial stability and profitability of Microcredit Bank. As a result of comprehensive reforms carried out for this purpose, the bank's assets in 2019 amounted to 1,972.0 billion soums. soums or 60 percent.

In addition, during the year, the bank and its branches have become one of the most active participants in the implementation of programs aimed at attracting the population to entrepreneurship. As a result, 38,305 customers received soft loans worth 906 billion soums. If we analyze them by sectors, 22.0 billion soums for 626 clients for handicrafts, 650.0 billion soums for 32553 clients under the program "Every family is an entrepreneur", 69.0 billion soums to 2938 clients to increase the efficiency of employment, 16.7 billion soums to 814 clients to improve the activities of farmers, dehkan farms and landowners, On the basis of the State Program "Youth - Our Future" and the principles of "Bank-Entrepreneur", "Entrepreneur-Bank" 362 clients received financial assistance of 125.0 billion soums [30. . 02. 2020]. 


\section{CONCLUSION}

In summary, research has shown that important steps have been taken in Uzbekistan to ensure the development of small business and entrepreneurship, to bring the industry to a new level, and loans provided by banks have become an important step in financing entrepreneurship and small business. Based on the research, effective reforms have been carried out in the country as a result of the specificity and liberalization of the independent banking system due to the formation of an active business environment in the history of independence, although some problems have arisen, it can be seen that the measures taken to eliminate these problems and their results have yielded certain results. It has played an important role in shaping the financial mechanisms for further development of small business and entrepreneurship in the country.

In particular, the formation of a new system of allocation of funds by banks on the basis of the principle of "Bank-Entrepreneur", "Entrepreneur-Bank" and the handling of applications of entrepreneurs showed the emergence of a new mechanism for solving problems in this area. One of the most effective ways to significantly increase the flow of investments in the country, to improve the business environment is to ensure the active participation of the country in recognized international rankings.

\section{REFERENCES}

1. History of Uzbekistan. Team of authors // Responsible editor R.H. Murtazaeva. (Textbook for non-specialty students of higher education institutions). -Tashkent:, 2003. -P 581.

2. Akimov Alexandr. Central Asia is a region in the World Economy //Central Asia Conflict Resolution and Change. Published by Douglas Goudie US, editors Roald Z. Sagdeev and Susan Einsenhower.1995. P.275- 293.

3. M. Onita. The Experience of Micro Credit in Kazakhstan, Uzbekistan and the Kyrgyz Republic // Central Asia2010. Prospects for human development, Regional Bureau for Europe and the CIS, UNDP, 2010. P.130140.

4. Usmonov Q, Sodiqov M, Burkhonova S. History of Uzbekistan. -Tashkent:, 2016. P. 388.

5. Oblomurodov N. Hazaratkulov A., Tolipov F. and others. History of Uzbekistan.Tashkent: ,2011. -P. 286-287.

6. Uz. MA. Fund- M-37, List 1, Volume 6298. P. 279.

7. Uz. MA. Fund- M-37, List 1, Volume 7594, P. 3.

8. Egamberdiev Sh. The role of small business and private entrepreneurship in overcoming the negative effects of the global financial crisis. // Factors of mitigation of the impact of the global financial and economic crisis on the economy of Uzbekistan and ways to overcome it. -Tashkent:, 2019. -P 63-64.

9. Musaeva S. Structural and social problems of entrepreneurship development in the context of economic liberalization (on the example of small businesses in Fergana region). // Candidate of Economic Sciences dissertation. -Tashkent:, 2005.- P. 89.

10. Our main goal is to ensure human interests, rights and freedoms, to make our lives more free and prosperous. Speech by President Islam Karimov at the 
Solemn Ceremony Dedicated to the 2oth Anniversary of the Constitution of the Republic of Uzbekistan.// People's Speech / December 8, 2012.

11. Ishquvatov V. History of self-government development in Uzbekistan. -Tashkent:, 2020. - P. 151.

12. Socio-economic development of postSoviet countries: results of the twentieth anniversary. (A team of authors). Moscow: IE RAS., 2012. -P. 344.

13. Abulqosimov $\mathrm{H}$, Kulmatov $\mathrm{A}$. The role of family business in small business in Uzbekistan and ways to develop it. Tashkent:. 2014.-P. 92.

14. Abulqosimov $\mathrm{H}$, Kulmatov A. Small business in Uzbekistan.. -P. 93.

15. Statistical collection. The main trends and indicators of economic and social development of the Republic of Uzbekistan in the years of independence (1990-2010) and forecasts for 2011-2015. Tashkent:, 2011. -P. 125.

16. Textbook on "Independence Lessons" on the occasion of the 25th anniversary of state independence of the Republic of Uzbekistan. -Tashkent:, 2016. -P. 52.

17. Neighborhood-private entrepreneurship and family business development center. Mahalla newspaper. -Tashkent: , 2015. -P. 38.

18. Karimova K. Small business and private entrepreneurship are the economic backbone of the country.// Scientific electronic journal "International Finance and Accounting”. №1, February, 2017.- P. 8.

19. Karimova K. Small business and private entrepreneurship are the economic backbone of the country.// Scientific electronic journal "International Finance and Accounting”. №1, February, 2017.- P. 8.

20. Ochilov J.J. Directions of state support of small business. // Economics and finance. // Economics and finance. -Tashkent:, 2017. №10. -P. 41.

21. Information of the Information Service of the Senate of the Oliy Majlis of the Republic of Uzbekistan. // Enlightenment. March 31, 2018, №26 (9091).

22. Karimova K. Small business and private entrepreneurship are the economic backbone of the country.// Scientific electronic journal "International Finance and Accounting”. №1, February, 2017.- P. 9.

23. Decree of the President of the Republic of Uzbekistan Shavkat Miziyoev "On the next measures to support the population and businesses during the coronavirus pandemic" .// People's speech. May 19, 2020. № 104.

24. Entrepreneurship development and ensuring guaranteed revenues to the state budget were analyzed.// People's speech. September 19, 2019, №189.

25. Address of the President of the Republic of Uzbekistan Shavkat Mirziyoyev to the Oliy Majlis - Tashkent: . 2019. -P. 20.

26. Resolution of the President of the Republic of Uzbekistan "On measures to further improve the rating of the Republic of Uzbekistan in the annual report of the World Bank and the International Finance Corporation" Doing Business // Collection of Legislation of the Republic of Uzbekistan. -Tashkent:. 2018.

27. For more information on the problems and shortcomings in the activities of business entities, see: Address of the President of the Republic of Uzbekistan 
Shavkat Mirziyoyev to the Oliy Majlis. Tashkent., 2019. -P. 20.

28. Presidential Decree of the President of the Republic of Uzbekistan "On measures to radically improve the investment climate in the Republic of Uzbekistan." // The word of the people-Tashkent:. 2018.

29. Murodov D. Entrepreneurs are supported in every possible way.// People's speech. 02.2020.

30. DAVLATOVA, K., \& NEMATOV, O. (2021). Tajiks of jizzakh oasis: traditional way of life, customs and traditions and rituals. Journal of Contemporary Issues in Business and Government| Vol, 27(3), 1325. 